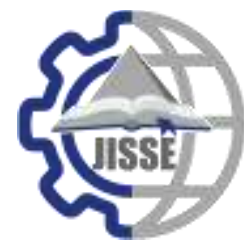

\begin{tabular}{ccc}
\hline \hline JISSE & $\begin{array}{c}\text { Journal of International Society for Science and Engineering } \\
\text { Vol. 2, No. 3, 58-64(2020) }\end{array}$ & JISSE \\
ISSN: 2636-4425 & ----------------------------------------------------------------- E-ISSN:2682-3438 \\
\hline
\end{tabular}

\title{
Solar Desalination by Humidification-Dehumidification Using Aspen plus Simulation
}

\author{
Esraa Khaled Mohamed ${ }^{1}$, Prof. Dr. Ahmed Soluman ${ }^{2}$, Prof. Dr. Omar El- Farok ${ }^{2}$, Prof. Dr. Ibrahim Ismail ${ }^{3}$ \\ ${ }^{1}$ Chemical Engineering Department, Faculty of Engineering, Tenth of Ramadan HTI, Egypt \\ ${ }^{2}$ Chemical Engineering Department, Faculty of Engineering, Cairo University, Egypt \\ ${ }^{3}$ Renewable Energy Program, Zewail City of Science and Technology, Egypt
}

\begin{tabular}{l} 
A R T I C L E I N F O \\
\hline Article history: \\
Received:09-11-2019 \\
Accepted: 10-05-2020 \\
Online: $15-05-2020$
\end{tabular}

\begin{tabular}{l}
\hline Keywords: \\
Solar Desalination \\
Humidification \\
Dehumidification \\
Aspen Plus simulation \\
Saline water \\
Solar Collector \\
\hline
\end{tabular}

\author{
Abbreviations \\ Concentrating photovoltaic-thermal (C-PV/T) \\ Electro-dialysis (ED) \\ Heating, ventilation, and air conditioning (HVAC) \\ Humidification dehumidification (HDH) \\ Membrane distillation (MD) \\ Multi-effect distillation (MED) \\ Multi-stage flash distillation (MSF) \\ Photovoltaic-thermal technology (PV-T) \\ Reverse osmosis (RO) \\ Solar still (SS) \\ Vapor compression distillation (VCD)
}

\section{Introduction}

Fresh water is the most important factor for daily life, as it is required for agricultural, drinking and industrial applications [1]. Despite of two thirds of the earth surface is water, only $1 \%$ of the world's water is used [2]. Saline water represents 97 $\%$ of the total available water resources on earth. Currently, one fifth of the world's population is facing scarcity in water resources. Therefore, finding fresh water resources has become important priority in the strategic plans of most governments as it affects the potential for social well-being of billions of people

"Esraa Khaled Mohamed, Msc at Cairo University, Chemical Engineer department, +201121677381, esraakhaled9466@ gmail.com

\begin{abstract}
A B S T R A C T
Most of desalination processes require a large amount of energy derived from natural gas and oil, which are non-renewable energy, to supply heat and electric energy. So, this paper depends on solar energy as a source of renewable energy, and can be powered for producing fresh water. The new idea depends on using simulation ASPEN-PLUS. The solar collector and air cooler is replaced by heater in simulation program, absorber and cooler are used instead of humidification-dehumidification device, and flash drum to separate fresh water from air after cooling process, certainly pressure drop occurred so compressor is used to raise pressure, in order to doing recycle of air after drying it. Venting of air before recycle process at 0\%, 25\%, 50\%, 75\% and 100\% is done. The simulation program is worked at Egyptian climate in summer and winter case. The maximum productivity of fresh water is at winter, when ratio of air to saline water is 3.47 with air temperature $250^{\circ} \mathrm{C}$.
\end{abstract}

[3]. The UN World Water Development Report showed that 3.7 billion people are affected by water scarcity; this number may be increase to 5.7 billion in 2050, while at present time 3.5 million people die annually due to inadequate water supply [6]. So, the aim of the global desalination market is accelerated rate of desalination from $9 \%$ at 2018 to $74 \%$ at 2022 [6].

Saline water desalination like other water treatments requires the use of energy to produce fresh water. The energy required depends on design of the plant, salinity and temperature of feed water, technology employed and the quality of the produced water [4].The best technique for saline water desalination is solar desalination process, because solar energy is renewable energy-powered technology, clean in use and available most time. While fossil fuel is non-renewable energy, and also burning fossil fuel produces amount of gasses that have environmental impact such as acid rains and greenhouse effects $[2]$.

Humidification dehumidification technique presents many advantages such as simplicity, flexibility in capacity, moderate operating costs and installation, and possibility of using low temperature energy sources. HDH process is applied when the fresh water demand is rather small. HDH units containing two exchangers: an evaporator where air is humidified with saline water and a condenser where distilled water is recovered. 
Comparing HDH to other distillation processes, the HD process works at atmospheric pressure. Productivity of distilled water was found to decrease when the water flow rate increase. The air flow rate was found to have an important effect on the productivity [5].

\section{Types of Solar desalination and solar cell}

The first desalination plant was established at World War II. Classification of solar desalination processes depend on target of process, which mean collect water or salt, collect water also classify to phase change or single phase, but classify of water collect depends on method of working. Figure 1 illustrates many desalination processes [8].

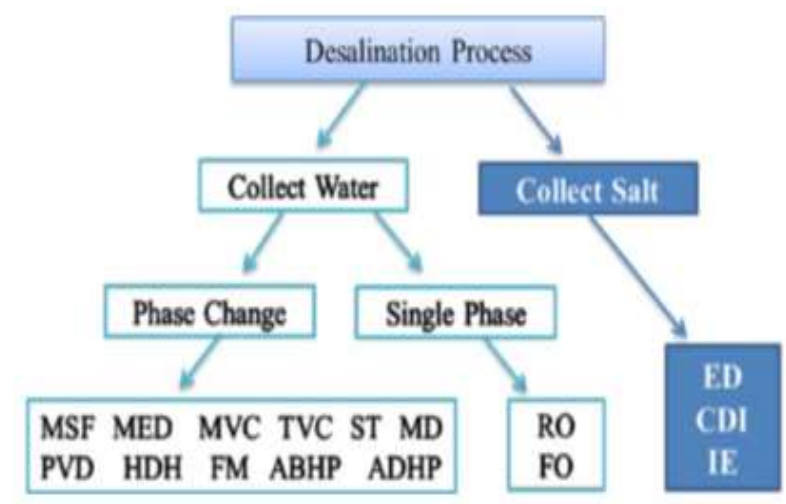

Figure 1: Desalination process grouped based on which substance is extracted (8)

\subsection{Humidification-dehumidification technology}

Solar collectors are used for heating water and air supply, or heating supply air only. HDH desalination process mainly consists of a humidifier (evaporator), dehumidifier (condenser). In humidification process, the water is direct contact with an unsaturated hot air and diffuses into the air, while at dehumidification; the water vapor is condensate in order to separate fresh water from air [7].

\subsection{Reverse Osmosis}

$\mathrm{RO}$ is a process depends on membrane desalination technique that has three units, firstly, pretreatment unit, secondly, a RO unit and finally post treatment unit. By using a high-pressure pump to pass pretreated water through a semi permeable membrane, which allows water pass to low concentration side and prevents salt particles from passing [3].

\subsection{Solar still}

SS is the oldest type of solar desalination the heat collection and distillation processes occur in the same device, where solar energy is used directly for distillation of saline water [8].

\subsection{Membrane Distillation}

MD is the thermal separation process which depends on membrane that transports water vapor across a microprocess which depends on membrane that transports water vapor across a micro porous hydrophobic membrane [9].

\section{5 .Types of Solar Collector}

The solar collector devices are used to collect solar radiation and then transfer the heat to the absorber fluid to increase internal energy to be used domestic application [10]. The thermal efficiency of solar collectors are between $60 \%$ and $75 \%$ [6], there are two type of solar collector; concentrating one such as parabolic trough. The temperature of the absorber tube reach up to $350-400^{\circ} \mathrm{C}$, and nonconcentrating one such as flat plate solar collector, to minimize heat loss thermal insulation and transparent screens are used [6].

\subsection{Concentrating $P V-T(C-P V / T)$}

The function of C-PV/Tis to produced heat and electric energy; first solar radiation is being absorbed and converted into heat, then the remaining is used to convert into electric energy by the PV cells. The overall efficiency of C-PV/T is $34.2 \%$ [11].

\section{Statement of the problem}

\subsection{Main idea of this work:}

This work mainly depends on idea of HumidificationDehumidification, but by using simulation program Aspen-Plus not experiential method. The study divides into theoretical study and simulation study, simulation study mainly depends on theoretical study, while theoretical study depends on papers that already published in journals.

\subsection{Theoretical study:}

The solar collector used in this study is parabolic line focus, because this device can heat oil up to $300^{\circ} \mathrm{C}$, which is suitable for Humidification dehumidification process. The main factor in this process is air. Firstly, the air is heated to be able to evaporate saline water, heating of air is 
occurred by two steps, first step, using parabolic line focus for heating thermal oil as it is difficult to heat air in solar collector as it is in vapor state, second air cooler is used to heat air by oil. The range of air temperature; after heating is between $100^{\circ} \mathrm{C}$ and $250^{\circ} \mathrm{C}$. Saline water is direct contact with hot air in absorber tower, saline water enters top of absorber while air enters at bottom. Finally, to get desired product (fresh water) cooler then flash drum is used.

\subsection{Simulation study:}

Humidification-Dehumidification process using AspenPlus will be discussed in the following steps:

- The heater in simulation program is for heating dried air, absorber and cooler are used instead of humidificationdehumidification device.

-In absorber (humidifier), air and saline water are at counter current flow, brine exits from bottom of absorber, humid air exits from top, then enter cooler (dehumidifier) in order to condensate water vapor.

-Flash drum is used to separate fresh water from air after cooling process.

-Certainly, pressure drop occurred so compressor is used to raise pressure, in order to doing recycle of air after drying it. -Before recycling process venting is occurred using splitter at percent of $0 \%, 25 \%, 50 \%, 75 \%$ and $100 \%$.

\subsection{Aim of this work:}

As it is known mineral salt in saline water cause corrosion of equipment, so the target of the work is to solve this problem, by heating of dry air and no heating of saline water so evaporation of saline water is occurred without heating of it. Using this method, the rate of corrosion is reduced, and equipment deprecation rate is decreased, this leads to reduction in cost.

\section{Methodology}

\subsection{Simulation using ASPEN-PLUS:}

Aspen Plus is based on techniques for solving flow sheets that were related to chemical engineers

The most frequently referenced documents were process flow diagrams (PFDs), which contain the basic process design information with material and energy balances.
Process simulation software is an excellent tool for producing high-quality PFDs. There are several process simulation software systems available to the chemical engineering community, and Aspen Plus is the most popular.

The solution of any flow sheet without recycle required an engineer to design each unit one at a time and, manually, introduce the solution values of a previously designed unit into the input of the next unit in the flow sheet. When it became necessary to deal with a recycle, the calculations began with a guess of the recycle values, and calculations ended when the values produced by the last unit in the loop matched the guesses. This requires much repetitive work and convergence was not guaranteed. This procedure evolved through the construction of rating models of units, as opposed to design models, which could be tied together by software in a way that emulated the procedure above and employed robust mathematical methods to converge the recycle elements of the process. This type of system is termed a sequential modular simulator [12].

\subsection{Conditions and climate at which Simulation is worked:}

The simulation is worked at Egyptian's climate, which means in summer case and in winter case, this is important in solar irradiation and condensation process. Solar irradiation in winter is nearly $200 \mathrm{~W} / \mathrm{M}^{2}$, in summer approximately $400 \mathrm{~W} / \mathrm{M}^{2}[13]$, At each case venting of air is calculated at $0 \%, 25 \%, 50 \%, 75 \%$ and $100 \%$. Heating of air is from $100^{\circ} \mathrm{C}$ to $250^{\circ} \mathrm{C}$.

\subsection{Process flow diagram for Solar Desalination:}

The following process flow diagrams exhibit the solar desalination process which is performed using Aspen-Plus program.

Figure 2, shows the process flow diagram with air venting, $25 \%, 50 \%, 75 \%$ and $100 \%$. While Figure 3 exhibits the desalination process without air venting for same conditions of the previous case. The only difference is the removal of the splitter. 


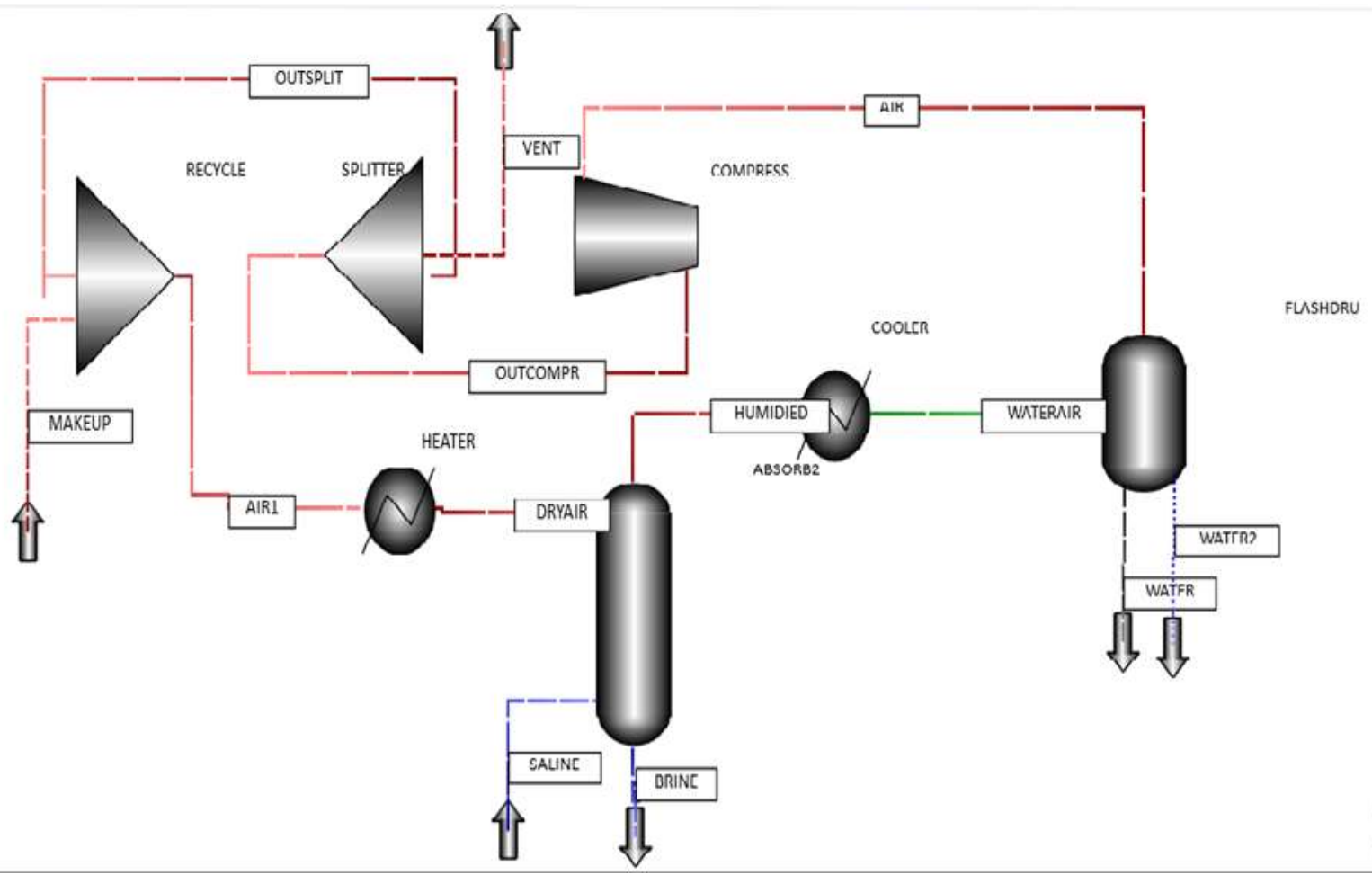

Figure 2: Solar desalination with venting using ASPEN-PLUS



Figure 3: Solar desalination without venting using ASPEN-PLUS 


\subsection{Conditions of production fresh water:}

There are ten cases each case with different ratio of air to saline water flow rate; there values are from 2 to 3.50 . Five cases are considered in winter and another five cases in summer, with different percentage of air venting cases each case with different ratio of air to saline water of air venting in both cases.

\section{Results and Discussions}

\subsection{Parameters that effect on productivity of fresh water:}

There are many parameters that are responsible for productivity of fresh water. Air is most important

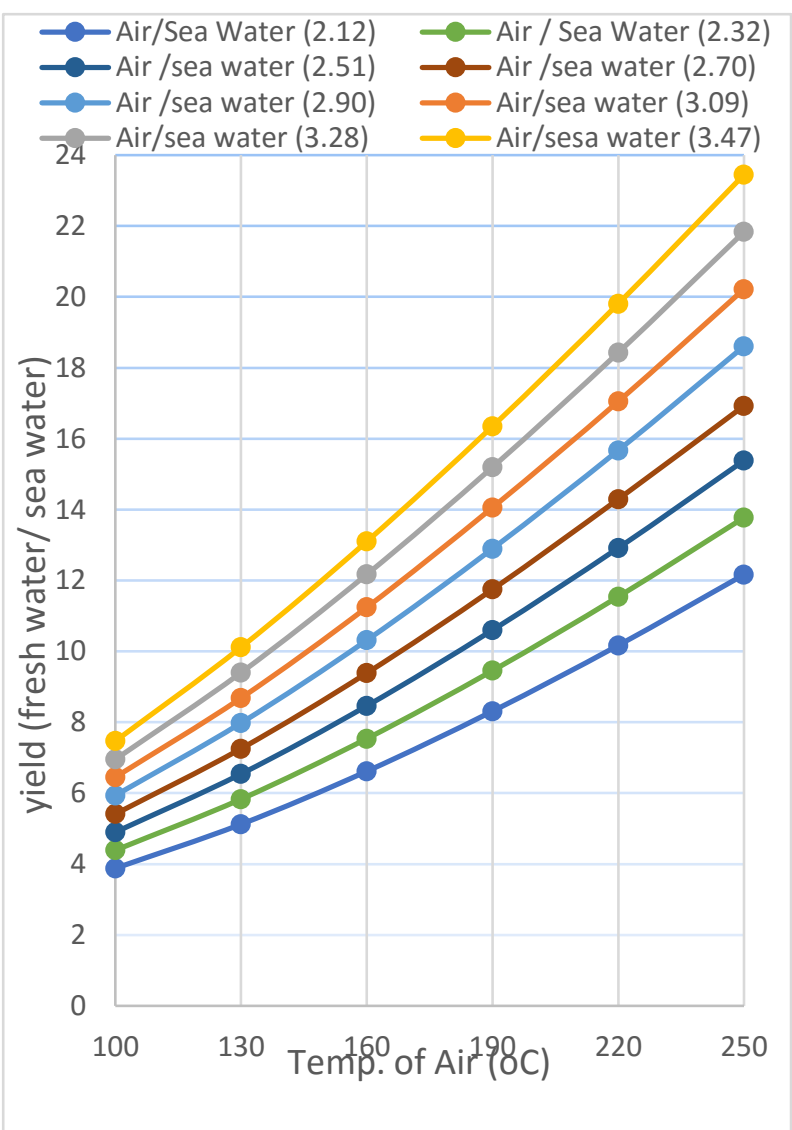

Figure 4: Yield vs. air temperature at winter with $0 \%$ air venting parameter, while saline water didn't prefer to be essential parameter, because heating of it increase rate of corrosion, increase flow rate of saline water with respect to air, decrease of productivity of fresh water. While temperature and flow rate of air are directly proportional with fresh water, venting of air doesn't have a perfect result, the following graphs are for yields, yield with respect to air temperature and also yield with respect to ratio between air to fresh water, Figures 4 and 5 show Yield with air temperature and Yield with air /fresh water at winter at $0 \%$ air venting, while Figure 6 to Figure 7 same conditions but at summer.



Figure 5: Yield vs. air /fresh water at winter with $0 \%$ air venting. 


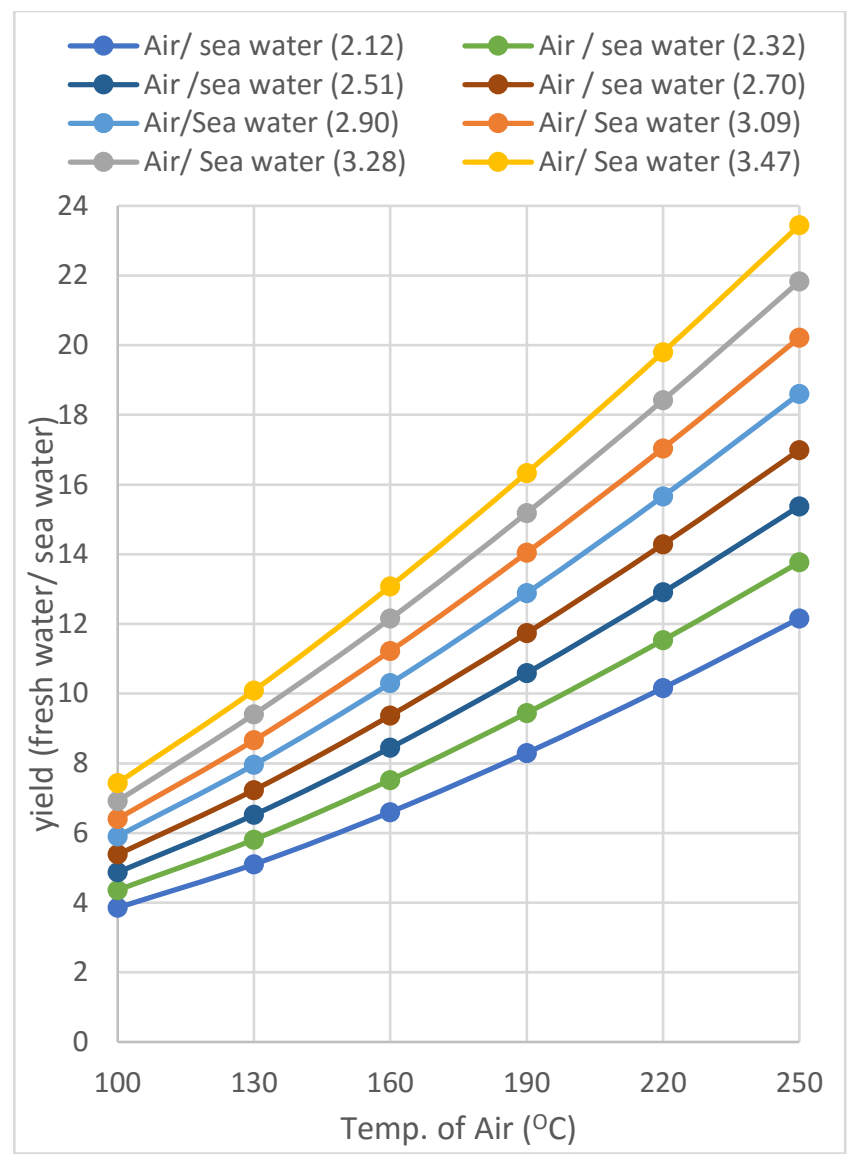

Figure 6: Yield vs. air temperature at summer with $0 \%$ air venting.

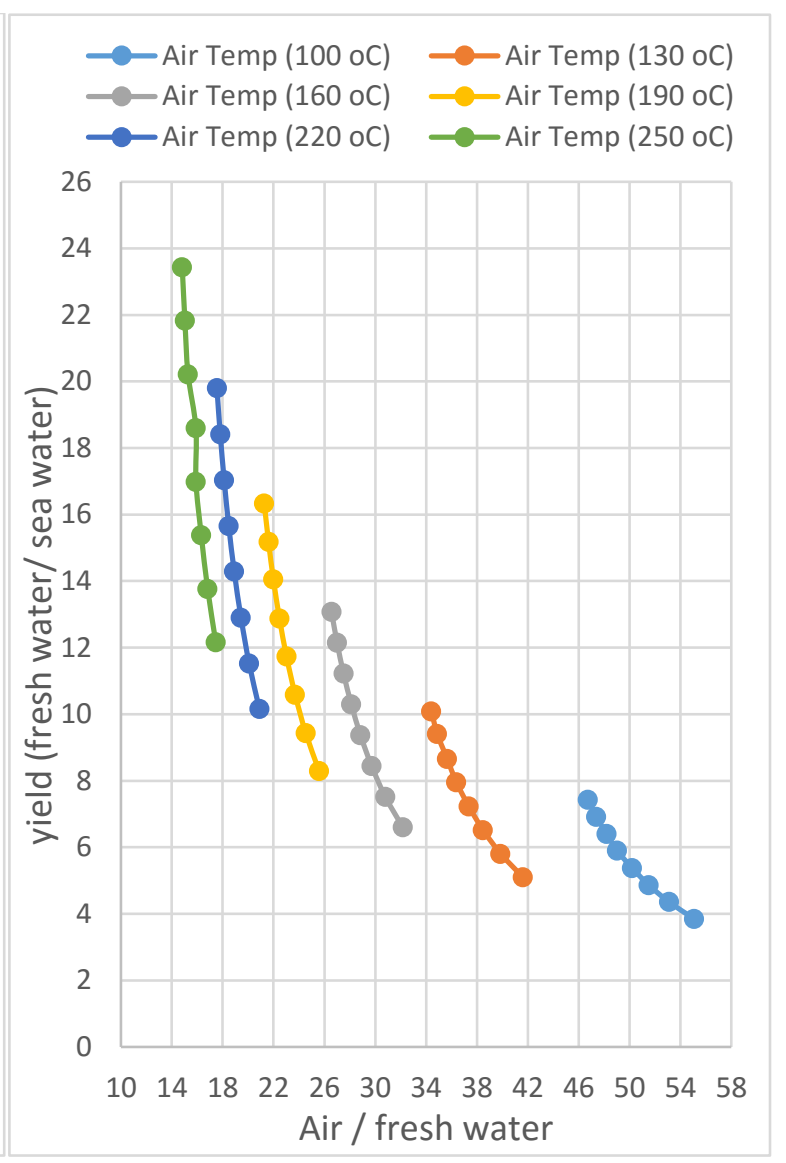

Figure 7: Yield vs. air/fresh water at summerwith0\% air venting.

From all study (yield with air temperature) in case of winteroptimum value in winter when air temperature $250^{\circ} \mathrm{C}$ then at 100 or summer was showed that, the maximum value of yield in each ${ }^{\circ} \mathrm{C}$, while at summer first optimum value at $100^{\circ} \mathrm{C}$ then $250^{\circ} \mathrm{C}$. case was at air temperature $250^{\circ} \mathrm{C}$ and air to sea water 3.47 , the highest value of all cases was at winter with $0 \%$ venting of air and equal to $23.45 \%$. The minimum value of yield in each one was at air temperature $100^{\circ} \mathrm{C}$ and air to sea water 2.12 , the lowest value of all cases was at summer with $100 \%$ venting of air and equal to $3.81 \%$.

The graphs that related to yield with air to fresh water, showed that in each case maximum and minimum yield was at air temperature $250^{\circ} \mathrm{C}$ and $100^{\circ} \mathrm{C}$ respectively, while air to fresh water decrease with increasing yield, the highest and lowest value of yield at all cases was at same condition with same value from pervious graphs.

\subsection{Determination of optimum values:}

The most important part in this study is determine optimum value, as known optimum value is the value that applied in plants, it is calculated by capacity of fresh water compared to feed of saline water divided by heat capacity required. The optimum value in both cases summer and winter is at ratio of ait to saline water 3.47 , but different in air temperature, the first

\subsection{Comparison with another works:}

The following comparison are between another study that depends on heating of saline water, and this study which depends on heating air only (14).Table 1 shows heating of sea water. While table 2 shows heating of air

Table 1: In case of heating of sea water

\begin{tabular}{|l|l|l|}
\hline Temp. of air $\left({ }^{\circ} \mathrm{C}\right)$ & $\begin{array}{l}\text { Flow rate of } \\
\text { air }(\mathrm{Kg} / \mathrm{Hr})\end{array}$ & $\begin{array}{l}\text { Flow rate of fresh } \\
\text { water }(\mathrm{Kg} / \mathrm{Hr})\end{array}$ \\
\hline 100 & 22000 & 402.21 \\
\hline 130 & 24000 & 530.95 \\
\hline 160 & 26000 & 685.74 \\
\hline
\end{tabular}

Table 2: Heating of air

\begin{tabular}{|c|c|c|}
\hline $\begin{array}{l}\text { Temp. of sea } \\
\text { water }\left({ }^{\circ} \mathrm{C}\right)\end{array}$ & $\begin{array}{l}\text { Flow rate of } \\
\text { air }(\mathrm{Kg} / \mathrm{Hr})\end{array}$ & $\begin{array}{l}\text { Flow rate of fresh } \\
\text { water }(\mathrm{Kg} / \mathrm{Hr})\end{array}$ \\
\hline 75 & 756 & 90.53 \\
\hline 80 & 540 & 84.60 \\
\hline 85 & 432 & 78.27 \\
\hline
\end{tabular}




\section{Conclusion}

From this study, using Aspen-plus as a simulation program to solve a flow sheet of solar desalination, by Humidification Dehumidification process, it was found that, the advantages were the fresh water free from any mineral salts, simple design of equipment used in this flow sheet, and solve corrosion problem by heating air without heating saline water, but low productivity of fresh water as recovery of water was small nearly $20 \%$. In order to increase productivity, require more heating of air temperature this mean require another solar collector that heating at more temperature, it is preferred to apply this system in pilot or large scale. The optimum values were determined to be at maximum ratio of air to saline water, in winter first value at $250^{\circ} \mathrm{C}$, then $100^{\circ} \mathrm{C}$, while in summer at temperature $100^{\circ} \mathrm{C}$ then $250^{\circ} \mathrm{C}$. It also found that venting of air didn't show perfect result, because it requires more heating of air with low productivity.

\section{References}

[1] N. A Elminshawy, F. R. Siddiqui, \&M. F.Addas, Experimental and analytical study on productivity augmentation of a novel solar humidificationdehumidification (HDH) system, Desalination, Vol. 365 PP. 36-37. 2015

[2]E. El-Bialy, S.M. Shalaby, A.E. Kabeel, \& A.M.Fathy, Cost analysis for several solar desalination systems, Desalination, Vol. 384, PP.12-30. 2015

[3] M. A. Abdel Kareem, M. El Haj Assad, E. T. Sayed, \&B. Soudan, "Recent progress in the use of renewable energy sources to power water desalination plants", Desalination, Vol.435, PP.97-113. 2018

[4] C. Ghenai, A. Merabet, T. Salameh, \&E. C.Pigem, " Gridtied and stand-alone hybrid solar power system for desalination plant", Desalination, Vol. 435, PP. 172-173, 2018

[5] E.H. Amer,H. Kotb, G.H. Mostafa, \&A.R.El-Ghalban, "Theoretical and experimental investigation of humidification-dehumidification desalination unit", Desalination, Vol.249, PP.949-959. 2009

[6] E. A.Farah, H.Raed \& H.Nidal, Solar powered desalination Technology, energy and future outlook, Desalination, Vol.453, PP.54-76. 2019.

\section{[13] THE SOLAR ATLAS OF EGYPT}

[14] W.F. He, F. Wu, T. Wen, Y.P. Kong\& D. Han, Cost analysis of a humidification dehumidification desalination system with a packed bed dehumidifier, Energy Conversion and Management, Vol.171, PP.452-460, 2018.
[7]E.H. Amer, H.Kotb, G.H. Mostafa \&A.R. El-Ghalban, Theoretical and experimental investigation of humidification-dehumidification desalination unit, Desalination, Vol.249, PP.949-959. 2009

[8] C. Li, Y. Goswami, \&E,Stefanakos, Solar assisted sea water desalination, Renewable and Sustainable Energy Reviews, Vol.19, PP.136-163. 2013

[9] J. G.Lee, W.Kim, J. Choi, N. Ghaffour, \&Y. Kim, Dynamic solar-powered multi-stage direct contact membrane distillation. System, Desalination, Vol. 435, PP.278-292. 2018

[10] P. Raj, \& S. Subudhi, A review of studies using nanofluids in flat-plate and direct absorption solar collectors, Renewable and Sustainable Energy Reviews, Vol.84, PP.54-74. 2018

[11] A. Chauhan, V.V. Tyagi, \& S.Anand, "Futuristic approach for thermal management in solar PV/thermal systems with possible applications", Energy Conversion and Management, Vol. 163, PP.314-354. 2018 